\title{
The Hazardous Activity of Yeasts Embedded in Biofilm and Planktonic Estimated Through the Effectiveness of four Commonly Used Biocidal Conditionings
}

\author{
DANIELA LORIN ${ }^{1}$, VALER TEUSDEA ${ }^{1}$, ELENA MITRANESCUㄴ, FLORIN MUSELIN ${ }^{2}$, EUGENIA DUMITRESCU², ADRIAN STANCU², \\ DUMITRU MILITARU', ROMEO TEODOR CRISTINA** \\ ${ }^{1}$ University of Agronomic Sciences and Veterinary Medicine Bucharest, 59 Marasti Blvd., 011464, Bucharest, Romania, \\ 2Banat's University of Agriculture and Veterinary Medicine King Michael I of Romania 119 Calea Aradului, 300645, Timisoara, \\ Romania
}

\begin{abstract}
The aim of study was to analyse the activity of four biocides. Assessment was made using the methodology described by the Clinical and Laboratory Standards Institute (CLSI); Antifungal Susceptibility Testing of Yeasts, M27-A3 Approved Standard, in: Candida sake, C. albicans, C. Iusitaniae and Rhodotorulla rubra. The outcome, related to the culture2 s cut-off value of optical density (O.D.) was analysed statistically $(p=0.05$ or lower) proving that Candida albicans was capable of generating strong biofilms, in the resistance setting $(p=0.001)$.
\end{abstract}

Keywords: biocides, fungi, biofilm, resistance

Due to the effective therapeutic strategies, microbiology has been swiftly advancing but, the quick-witted fungi remain those that have the ability to decide about their eco-evolution and the way they are manifested. Numerous studies describe the role of biofilm, in greater extent, the bacterial, and in lesser extent, the fungal, suggesting reliable control means for it [1-3]. Biofilm produced by Candida, can form everywhere. It can be found on living or inert surfaces, in humid environment [4], from pipes and installation surfaces in livestock and food industry [5], domestic setting [6], dental and orthopaedic prostheses [7], cardiovascular devices [8], contact lenses [9], urinary catheters, implants, tracheal tubes etc. [10]. It has been shown that inside the biofilm, the organisms behave differently, become more resistant and exhibit large dimorphism in their expansion [11-13].

Antifungal biocides, unlike antibiotics, (which act selectively on the target cell), are acting on one or more sites, such as: cell wall, proteins, enzymes, ribosomes and DNA. Furthermore, an increase in resistance rate to antibiotics/ antifungal products, biocides/ decontaminating products, and a redistribution of various microorganism species to one, or more than one, cellular structures/sites, have been detected, and this, is regularly followed by undesirable effects in humans and animals [14-16]. Several methods, from non-standardised to standardised have been proposed, with the antifungal susceptibility testing (AST) becoming an accepted methodology for human and veterinary mycology. Various approaches for determining the fungal susceptibility to biocides are based on principles used in antibiograms [17-20]. The microplate technique is easy to use for both bacteria and fungi, and can be adapted in various test settings [21-24].

Our previous research carried out in animal farms, have investigated 544 strains from 9 genera of filamentous fungi and two yeast genera. From all the isolated strains, Aspergillus and Candida had the highest occurrence rate (42.4\%) [25]. The analysis has revealed that bedding and surfaces that come in contact with animals, including watering and feeding systems, were the most involved, confirming that these are crucial sources of the fungal infection in animal facilities, and for which the action of biocides is required [26-29].
In this paper, it is presented an efficiency study, broadly relevant, of four biocide treatments commonly used in the veterinary field against yeasts, using the Minimal Fungicide Concentration methodology, with the aim of displaying them resistance tendency.

\section{Experimental part}

The composition of commercial biocides and the dilutions used for testing the biocidal effect in our analysis, are presented in table 1 .

Biocidal evaluation was done using the methodology described by Clinical and Laboratory Standards Institute (CLSI), Antifungal Susceptibility Testing of Yeasts; Approved Standard - Third Edition M27-A3 [23]. Yeast strains used were: Candida sake, C. albicans, C. lusitaniae and Rhodotorulla rubra, isolated from the sanitation samples collected in the visited farms.

\section{The yeast isolation and identification}

Sampling was performed according to the Romanian norm of sampling [30] and the EU methodology. Identification was based on cultural, macro / microscopic and biochemical features found in literature [31, 32].

\section{Biofilms cultivation and examination}

To obtain the biofilms in vitro, a model proposed was used after Shin [8] and the quantification of results was adapted from an experimental model described by Djordjevic [18]. All the tests were performed in duplicates, with the biofilm evaluation being expressed in optical density units (O.D.). Interpretation of results was done after Stepanoviæ [33], by relating to a cut-offvalue O.D. (or O.D.C threshold interpretation. To evaluate cells viability embedded in biofilm, staining with resazurin, a cellular redox indicator, was performed, after Sittampalam [34].

\footnotetext{
The Minimum Fungicidal Concentration (MFC) methodology

A settled amount of fungal culture was put into contact with serial dilutions of the biocide. After $24 \mathrm{~h}$ incubation, the culture appearance in the liquid medium was observed.
} 


\begin{tabular}{|c|c|c|c|c|c|c|c|c|c|c|c|c|}
\hline \multicolumn{7}{|c|}{ Tested biocide / concentration (\%) } & \multicolumn{6}{|c|}{ Composition of the commercial conditionings } \\
\hline \multicolumn{7}{|c|}{ ( } & \multirow{2}{*}{\multicolumn{6}{|c|}{$\begin{array}{l}\text { Glutaraldehide, } \\
\text { Alkyl dimethylbenzyl ammonium chloride, } \\
\text { Didecyl dimethyl ammonium chloride, } \\
\text { Ethyl alcohol. }\end{array}$}} \\
\hline 5.0 & 4.0 & \multicolumn{2}{|r|}{$1.0^{2}$} & \multicolumn{2}{|r|}{$0.5^{2}$} & $0.25^{\circ}$ & & & & & & \\
\hline \multicolumn{7}{|l|}{ B } & \multirow{2}{*}{\multicolumn{6}{|c|}{$\begin{array}{l}\text { Alkyl dimethylbenzyl ammonium chloride, } \\
\text { Didecyl dimethyl ammonium chloride. }\end{array}$}} \\
\hline 4.5 & 3.5 & \multicolumn{2}{|c|}{$2.5^{\text {s. }}$} & \multicolumn{3}{|c|}{1.0} & & & & & & \\
\hline \multicolumn{7}{|l|}{$\mathrm{C}$} & \multirow{2}{*}{\multicolumn{6}{|c|}{ Chlorhexidine digluconate. }} \\
\hline 3.0 & $2.0^{2}$ & & 1.0 & & 0.5 & 0.25 & & & & & & \\
\hline \multicolumn{7}{|l|}{ D } & \multirow{2}{*}{\multicolumn{6}{|c|}{$\begin{array}{l}\text { Formaldehyde, } \\
\text { Alkyl dimethylbenzyl ammonium chloride. }\end{array}$}} \\
\hline 6.0 & 5.0 & & 4.0 & & 2.0 & 0.5 & & & & & & \\
\hline \multicolumn{13}{|c|}{ Biocide / Concentration $\%$} \\
\hline \multirow{4}{*}{ 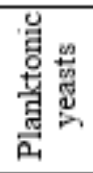 } & A & 3.0 & & 2.0 & & 1.0 & 0.125 & 0.062 & 0.031 & 0.015 & - & - \\
\hline & B & 3.50 & & 1.75 & & 0.875 & 0.437 & 0.218 & 0.109 & 0.054 & - & - \\
\hline & $\mathrm{C}$ & 1.50 & & 0.75 & & 0.375 & 0.187 & 0.092 & 0.046 & 0.023 & - & - \\
\hline & $\mathrm{D}$ & 6.0 & & 3.0 & & 1.50 & 0.75 & 0.375 & 0.187 & 0.093 & 0.046 & 0.023 \\
\hline \multirow{4}{*}{ 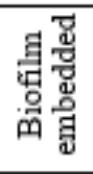 } & A & 3.0 & & 2.0 & & 1.0 & 0.125 & 0.062 & 0.031 & 0.015 & - & - \\
\hline & B & 5.0 & & $\$ 3.50$ & & 1.75 & 0.875 & 0.437 & 0.109 & 0.054 & - & - \\
\hline & $\mathrm{C}$ & 3.0 & & 2.0 & & 1.50 & 0.75 & 0.375 & 0.187 & 0.092 & - & - \\
\hline & $\mathrm{D}$ & 12.0 & & 5.0 & & 3.0 & 1.50 & 0.75 & 0.375 & 0.187 & $1 * 0.093$ & $* 0.046$ \\
\hline
\end{tabular}

Legend: a - manufacturer recommended concentration for the necessary decontamination; $b$ - manufacturer recommended concentration for prophylactic decontamination; *for Candida lusitaniae the initial dilution was 3.5\%;

**only for Rhodotorulla rubra dilutions $0.093 \%$ and $0.046 \%$ were tested.

\section{Statistical methods}

The statistical analysis was performed on compared optical density (O.D.) values, by GraphPad Prism 5.0 for Windows (GraphPad Software, USA) Nonparametric Friedman test was used in analysis and Dunn's Multiple Comparison as a post-test, to $p=0.05$ or less.

\section{Results and discussions}

Evaluation of biocides on planktonic yeasts

Tables 2 and 3 present the biocides efficiency assay results.

The analysis revealed that the concentrations recommended by the manufacturer for tested A-D biocides, were higher than the Minimum Fungicidal Concentrations (MFC) determined, suggesting that tested biocides are effective at the concentrations recommended only in yeast strains tested in planktonic state. Data has shown that biocides $A, B$ and $C$ at the concentrations recommended by the manufacturer's guide, both for prophylactic and necessary decontamination, were lower than MFC determined for some yeast strains embedded in biofilm.

Evaluation of the biocides on yeast strains embedded in biofilms

To assess the biocidal activity of the commercial products on yeast strains embedded in biofilm, using MFC was determined: a). yeast isolates ability to form biofilms; b). yeast cell viability embedded in biofilms and, c). microscopical examination of the produced biofilms.

\section{Testing the yeast cell viability embedded in biofilms}

Out of 23 yeast strains that formed biofilm, seven were selected to determine their viability in the biofilm: (1). Rhodotorulla rubra - strain 2; (2). C. albicans - strain 6; (3). C. Iusitaniae - strain $1 ;(4)$. C. sake - strain $1 ;(5)$ C. famata - strain 1; (6). C. rugosa-strain 1 and (7). C. albicans-strain 5.

For each strain it was allocated one column / row (a-h) with 8 wells: 1 (a-h) - Rhodotorulla rubra strain 2; 2 (a-h) Candida albicans strain 6; 3(a-h) - Candida lusitaniae strain 1; 4 (a-h) - Candida sake strain 1; 5 (a-h) - Candida famata strain 1; 6 (a-h) - Candida rugosa strain 1; 7 (a-h) - Candida albicansstrain 5; 8(a-h) - Negative control - Culture medium only.

The microplates appearance with: formed biofilm (A), before incubation and after resazurin coloration $(B)$, the presence of living cells after the microplates incubation (C and $D$ ) of the seven yeasts strains studied and the negative control are presented in figure 1.

\section{Microscopy of the biofilm}

The yeast samples, after colouring with white calcofluor, appeared as light green. The microscopic images of biofilm formed at the maqnification x 25 is shown in figure 2 .

\begin{tabular}{|c|c|c|c|c|c|c|c|c|c|c|c|}
\hline \multirow{3}{*}{\multicolumn{2}{|c|}{ Studied strains }} & \multicolumn{10}{|c|}{$\begin{array}{l}\text { Recommended Concentration } \\
\text { Minimum Fungicidal Concentration (MFC) }(\%)\end{array}$} \\
\hline & & \multicolumn{4}{|c|}{$\mathrm{A} \%$} & \multicolumn{2}{|c|}{$\mathrm{B} \%$} & \multicolumn{2}{|c|}{$\mathrm{C} \%$} & \multicolumn{2}{|c|}{$\mathrm{D} \%$} \\
\hline & & MFC & 0.25 & 0.50 & 1.0 & MFC & 0.25 & MFC & 2.0 & MFC & 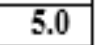 \\
\hline \multirow{2}{*}{$\begin{array}{l}\text { Candida } \\
\text { sake }\end{array}$} & $M B$ & 2.0 & 8.0 & 5.0 & 2.0 & 5.0 & 20.0 & 3.0 & 1.50 & 3.0 & 1.66 \\
\hline & & & & 8.06 & 16.12 & 0.109 & & 0.092 & 21.73 & 0.093 & 53.7 \\
\hline \multirow{2}{*}{$\begin{array}{l}\text { Candida } \\
\text { albicans }\end{array}$} & & & & 6.0 & 30 & & & & 1.50 & 50 & 1.0 \\
\hline & & & 4.03 & 8.06 & 16.12 & 0.109 & 2.29 & 0.375 & 5.33 & 0.093 & 53.7 \\
\hline \multirow{2}{*}{$\begin{array}{l}\text { Candida } \\
\text { lusitaniae }\end{array}$} & E. & 1.0 & 4.0 & 2.0 & 1.0 & 3.50 & 14.0 & 1.50 & 1.33 & 0.75 & 6.66 \\
\hline & & & 4.03 & 8.06 & 16.12 & 0.109 & 2.29 & 0.18 & 10.69 & 0.093 & 53.7 \\
\hline \multirow{2}{*}{$\begin{array}{l}\text { Rhodotorulla } \\
\text { rubra }\end{array}$} & & 0.0 & 4.03 & 8.06 & 16.12 & 0.218 & 1.14 & 1.50 & 1.3 & 0.187 & 26.7 \\
\hline & $A_{1}$ & $\overline{003}$ & 8.06 & 16.12 & 32.25 & 0.109 & 2.29 & $<0.02$ & $<86.9$ & 0.093 & 53.7 \\
\hline
\end{tabular}

Table 2

COMPARATIVE RATIO BETWEEN THE RECOMMENDED CONCENTRATIONS FOR BIOCIDES A, B, C, AND D (\%) AND THE MINIMUM FUNGICIDAL CONCENTRATIONS (MFC) ASCERTAINED

Legend: $E M B=$ embedded in biofilm; PLA = planktonic strains 


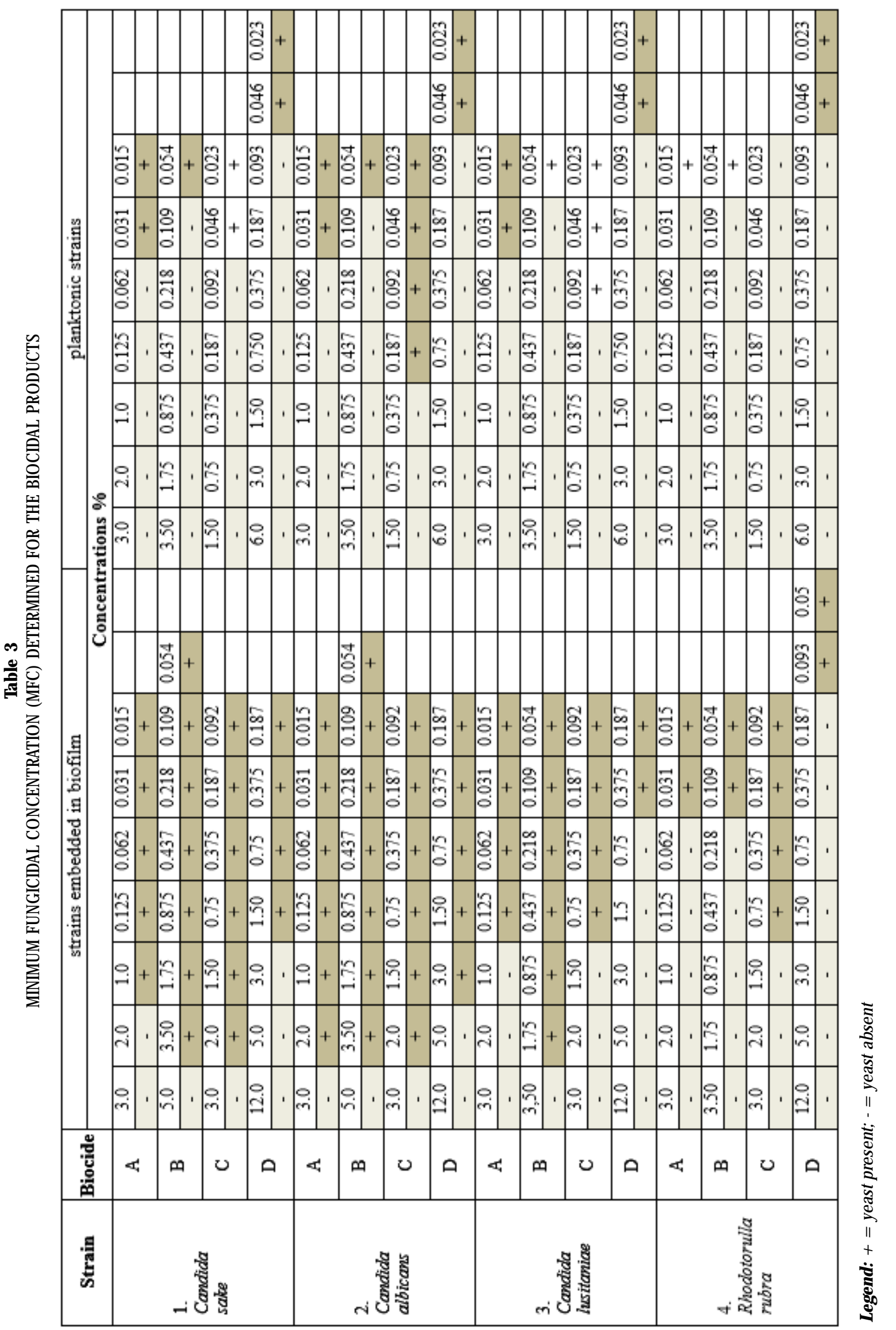

The images presented in figure 2 , have shown that embedded yeast cells generated biofilm from all categories, from strong to weak. Microplates observation has revealed an active metabolism confirming the presence of live cells. Statistical data analysis revealed, that if the tests are repeated under the same conditions (standard deviation = 1.3268; standard error $=0.2708$ ), the average of cases (1.2817), will be within $95 \%$ and

within the (lowest- upper) confidence interval $I_{95}=0.7214$ to 1.8420 , and $5 \%$ outside this range. The results obtained at a probability of $p=0.05$ and a value of $t=2.069$, value corresponding to freedom degrees of $n-1$, do not exceed the value of $2 \pm t s$, that is in the range $(-0.7451 ;+4.7451)$. In figure 3 , the statistical analysis have shown a significant capability of Candida strains, and in particular Candida albicans, to form strong biofilms ( $p=0.001)$. 


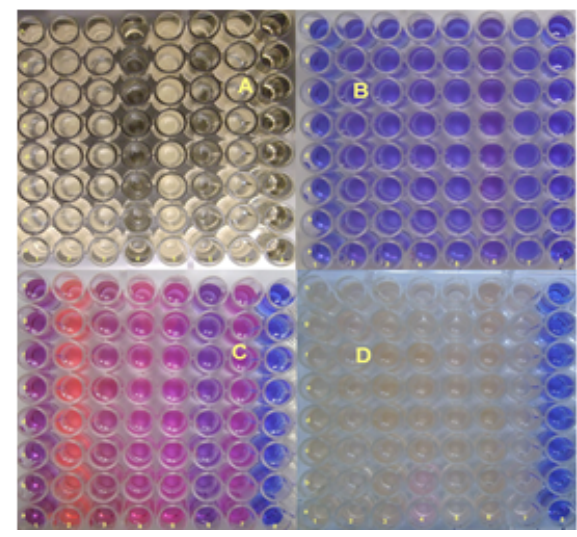

Fig. 1. The microplates aspect of yeasts embedded in biofilm.

A - appearance of biofilm and negative control microplate. Biofilm appears as a yellowishwhite deposit, adhering to the 1-7 (a-h) microplate wells bottom and 8 (a-h) negative

control column: no deposit and clear content.

B - the biofilm aspect stained with resazurine before incubation. Biofilm's blue color can be observed after the staining.

$C$ - the biofilm aspect after incubation. The color change from blue to various shades of pink or colourless in columns 1-7 (a-h) can be observed, suggesting the presence of viable yeast cells in the biofilms. Color of the line 8 (a-h), reserved for the negative control remained unchanged, respectively blue.

D - the biofilm aspect after extended time incubation. The presence of viable cells can be observed in columns 1-7 (a-h), the negative control remained unchanged, respectively blue
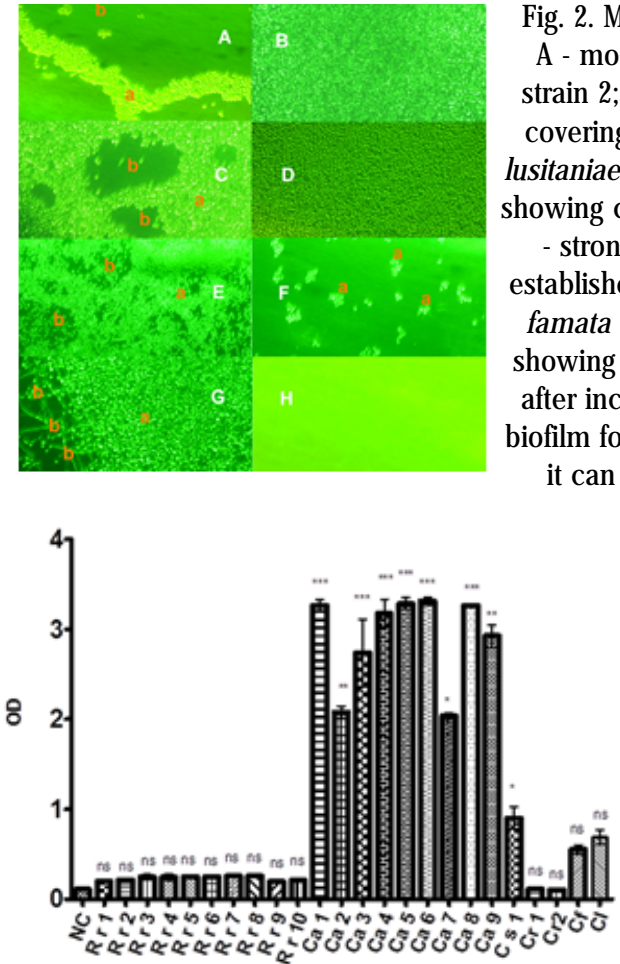

Fig. 3. The comparative statistics of biofilm development degree in the studied yeasts

Compared with: Negative Control $(\mathrm{NC})=\mathrm{ns}=$ not significant; $*=p<0.05 ; * *=p<0.01 ; * * *=p<0.001$.

$\mathrm{Rr}=$ Rodotorulla rubra; $\mathrm{Ca}=$ Candida albicans; $\mathrm{Cs}=\mathrm{C}$. sake; $\mathrm{Cr}=\mathrm{C}$. rugosa; $\mathrm{Cf}=\mathrm{C}$. famata; $\mathrm{Cl}=\mathrm{C}$. lusitaniae

Study of the role of fungi remains a current topic because of its medical importance, frequency, and recurrence of emerging infections. In the last decade, the presence of Candida albicans - related infections, associated with biofilm formation, became a significant threat, confirmed in the various fungal resistance mechanisms exerted [13].

This study allow ed us to measure the efficacy evolution of four commonly used biocide treatments against yeasts in planktonic and biofilm environments. Statistical data have shown that the yeasts embedded in biofilms are certainly number one enemies in the antifungal sanitation fight. Despite the fact that methodology used here was adapted from microbiology, the techniques utilised, proved to have a high grade of accuracy also in mycology, observation also confirmed by other studies $[1,20,34]$.

Our results bear a resemblance to the values shown by other authors who demonstrated that Candida cells within a biofilm structure show a reduced susceptibility to specific commonly used antifungals [35]. We have also demonstrated in our study of biocide $\mathrm{C}$, that it was ineffective at the recommended concentration of $2 \%$, on biofilm formed by Candida albicansand in smaller extent by $C$. sake. In spite of the fact that $C$. albicans is still considered the most frequent candidian pathogen, we also observed an increase in the presence of Candida rugosa, Candida lusitaniae, Candida sake, Candida famata, with the last three producing a strong biofilm and impeding with time the biocidal structures in decontamination, suggesting a future direct or indirect resistance. This observation has also been previously made by other researchers in human and veterinary field [36-39].

The vibrant evolution of fungi constitutes an important issue, with the multifaceted defence measures being required to tackle them. These are not easy to eradicate and thus, became a significant threat, confirmed by the fungal resistance mechanisms presented in literature and regulated by the European legislation [40].

\section{Conclusions}

It was ascertained that Candida spp. and especially Candida albicans are capable to generate strong biofilms, as a prime step in the resistance tendency setting, with high significant statistical probability $(p=0.001)$. This deleterious activity was proven by the biocides' efficiency results in the case of Candida albicans embedded in biofilms, where products $A, B$ and $C$ tested, have proven to be inefficient to certain concentrations, usually recommended in necessity or prophylactic decontamination. This study warns about the hazardous and highly dynamic characteristic of resistance predisposition for Candida albicans embedded in biofilms, providing information that will enable some restored considerations about the prevalence of these yeasts.

Acknowledgements: This work was possible due to POSDRU project; ID: 76888, co-funded by European Social Fund, through the Human Resources Development Operational Sectorial Programme 2007-2013.

\section{References}

1.CHANDRA, J., KUHN, D.M., MUKHERJEE, P.K., HOYER, L.L., MCCORMICK, T., GHANNOUM, M.A., J. Bacteriol., 183, 2001, p. 5385. 
2.DOUGLAS, L.J., Trends Microbiol., 11, 2001, p. 30.

3.HALL-STOODLEY, L., COSTERTON, J.W., STOODLEY, P., Nature Rev. Microbiol., 2, 2004, p. 95.

4.THEIN, Z.M., SENEVIRATNE, C.J ., SAMARANAYAKE, Y.H.,

SAMARANAYAKE, L.P., Mycoses, 52, 2009, p. 467.

5.SALA, C., MORAR, A., COLIBAR, O., MORVAY, A.A.,

Rom. Biotechnol Lett. 17, 2012, p. 7483.

6.GILBERT, P., MCBAIN, A.J., J. Infect., 43, 2001, p. 85.

7.SUSEWIND, S., LANG, R., HAHNEL, S., Mycoses, 58, 2015, p. 719.

8.SHIN, J.H., KEE, S.Y., SHIN, M.G., J. Clin. Microbiol., 40, 2002, p. 1244.

9.IMAMURA, Y., CHANDRA, J., MUKHERJEE, P.K., LATTIF, A.A.,

SZCZOTKA-FLYNN, L.B., PEARLMAN, E., LASS, J.H., O'DONNELL, K., GHANNOUM, M.A., Antimicrob. Agents Chemother., 52, 2008, p. 171.

10.DUNNE, W.M., J. Clin. Microbiol., 15, 2002, p. 155.

11.BAILLIE, G.S., DOUGLAS, L.J., J. Antimicrob. Chemother. 46, 2000, p. 397.

12.LI, X., YAN, Z., XU, J., Microbiology, 149, 2003, p. 353.

13.RAMAGE, G., MARTÍNEZ, J.P., LÓPEZ-RIBOT, J.L., FEMS Yeast Res., 6, 2006, p. 979.

14.MCDONNELL, G., RUSSELL, A.D., Clin. Microbiol. Rev., 12, 1999, p. 147.

15.RUSSELL, A.D., FURR, J.R., Sci. Prog., 79, 1996, p. 27.

16.SANGLARD, D., ISCHER, F., MONOD, M., BILLE, J., Antimicrob. Agents Chemother. 40, 1996, p. 2300.

17.BUNGAARD-NIELSEN, K., NIELSEN, P.V., J. Food Protect., 59, 1996, p. 268.

18.DJ ORDJ EVIC, D., WIEDMANN, M., MCLANDSBOROUGH, L.A., Appl. Environ. Microbiol., 68, 2002, p. 2950.

19.FOTHERGILL, W.A. Antifungal Susceptibility Testing: Clinical Laboratory and Standards Institute (CLSI) methods. In: Interactions of Yeasts, Moulds, and Antifungal Agents: How to Detect Resistance, Hall GS (Ed.), XIV, 65-74, Humana Press, USA, 2012.

20.RAMAGE, G., VANDLE-WALLE, K., WICKES, B.L., LÓPEZ-RIBOT, J.L., Antimicrob. Agents Chemother. 45, 2001, p. 2475.

21. *** AlHA (American Industrial Hygiene Association). Field Guide for the Determination of Biological Contaminants in Environmental Samples Second Edition Hung LL, Miller JD, Dillon HK (Eds.), Fairfax, VA, Canada, 2005.

22.*** AOAC (Association Of Analytical Communities). Official Methods of Analysis of the AOAC International, Chapter 6, Disinfectants, AOAC

Official Method 955.17 Fungicidal Activity of Disinfectants. Current edition, Gaithersburg, MD, USA, 2015.

23.*** CLSI (Clinical and Laboratory Standards Institute). Performance Standard for Antimicrobial Disc Susceptibility Tests; M2-A9 Approved Standard. Ninth Edition, 2006.
24.*** EUCAST (European Committee on Antimicrobial Suscceptibility Testing). Method E.DEF 7.2 for determination of broth dilution of antifungal agents for fermentative yeast, revised March 2012.

25.LORIN, D. Researches on the cidal activity of some commercial products used in decontamination programs in poultry and swine breeding units and fungi isolated from them. PhD thesis, Faculty of Veterinary Medicine Bucharest, Romania, 2014.

26.LORIN, D., STANCU, A.C., TEUSDEA, V., MITRANESCU, E., CRISTINA, R.T., ORBOI, D., POPOVICI, R.A., PENTEA, M.C., Rev. Chim. (Bucharest), 66, no. 12, 2015, p.1978.

27.FULLERINGER, S.L., SEGUIN, D., WARIN, S., BEZILLE, A., DESTERQUE, C., ARNE, P., CHERMETTE, R., BRETAGNE, S., GUILLOT, J., Poult. Sci.,85, 2006, p. 1875.

28.MAYEUX, P., DUPEPE, L., DUNN, K., BALSAMO, J., DOMER, J., Appl. Environ. Microbiol., 61, 1995, p. 2297.

29.VIEGAS, C., CAROLINO, E., MALTA-VACAS, J., SABINO, R., VIEGAS, S., VERISSIMO, C., Fungal contamination of poultry litter: a public healthproblem. J. Toxicol. Environ. Health A. 75, 2012, p. 1341.

30.*** ANSVSA (Autoritatea Naionala Sanitara Veterinara si pentru Sigurana Alimentelor) 2008. Ordin nr. 25 din 19 martie 2008 pentru aprobarea Normei sanitare veterinare privind metodologia de prelevare, prelucrare primara, ambalare si transport al probelor destinate examenelor delaboratorîn domeniul sanatatii animalelor (in Romanian).

31.ELLIS, D., DAVIS, S., ALEXIOU, H., HANDKE, R., BARTLEY, R., Description of medical fungi, Second Edition, Nexus Print Solutions Adelaide,South Australia, 2007.

32.HOOG, G.S., GUARRO, J., GENE, J., FIGUERAS, M., Atlas of clinical fungi. Second Edition, Centraalbureau voor Schimmelcultures (CBS), Utrecht, The Netherlands, 2000.

33.STEPANOVIC, S., VUKOVIC, D., DAKIC, I., SAVIC, B., SVABICVLAHOVIC, M., J., Microbiol. Methods, 40, 2000, p. 175.

34.SITTAMPALAM, G.S. Assay Guidance Manual; Eli Lilly \& Company and the National Center for Advancing Translational Sciences. 2014. 35.MATHÉ, L., VAN DIJCK, P., Curr. Genet., 59, 2013, p. 251.

36.AL-FATTANI, M.A., DOUGLAS, L.J., J. Med. Microbiol., 55, 2006, p. 999.

37.KIM, J.Y., J. Microbiol., 54, 2016, p. 145.

38.KUMAMOTO, A.C., Curr. Opin. Microbiol., 5, 2002, .p 608.

39.THERAUD, M., BEDOUIN, Y., GUIGUEN, C., GANGNEUX, J.P., J. Med. Microbiol., 53, 2004, p. 1013.

40.*** REGULATION 528/2012. Of the European Parliament and of the Council of 22 May 2012 concerning the making available on the market and use of biocidal products. Official Journal of the European Union L 167, 2012, p. 1.

Manuscript received: 9.12.2016 